\title{
Review
}

\section{The role of Bcl-2 and its pro-survival relatives in tumourigenesis and cancer therapy}

\author{
PN Kelly ${ }^{1,2,3}$ and A Strasser ${ }^{*, 1,2}$
}

Tumour development requires a combination of defects that allow nascent neoplastic cells to become self-sufficient for cell proliferation and insensitive to signals that normally restrain cell growth. Among the latter, evasion of programmed cell death (apoptosis) has proven to be critical for the development and sustained growth of many, perhaps all, cancers. Apoptotic cell death is regulated by complex interactions between pro-survival members and two subgroups of pro-apoptotic members of the B-cell lymphoma-2 (Bcl-2) protein family. In this invited review article, we reminisce on the discovery of Bcl-2, the first regulator of cell death identified, we discuss the mechanisms that control apoptotic cell death, focussing on how defects in this process promote the development and sustained growth of tumours and also affect their responses to anticancer therapeutics and, finally, we describe how current knowledge of the regulatory networks of apoptosis is exploited to develop novel approaches for cancer therapy.

Cell Death and Differentiation (2011) 18, 1414-1424; doi:10.1038/cdd.2011.17; published online 18 March 2011

Nearly 40 years ago, Kerr et al. ${ }^{1}$ first proposed that cellular hyperplasia, which often constitutes a forerunner of a malignant tumour, could result from abnormally decreased cell death and not only from abnormally increased cell proliferation. The demonstration of cell death in normal adult tissues confirmed the hypothesis that cells must continuously be lost to balance cell proliferation for maintaining homeostasis in healthy tissues. ${ }^{1}$ Programmed cell death (apoptosis) is now widely recognised as an evolutionarily conserved, genetically controlled process for killing damaged, infected, superfluous or potentially dangerous cells that is essential for the normal development and function of multicellular organisms (reviewed in Strasser et al. ${ }^{2}$ ). Defects in the control of apoptosis causing either the survival of unwanted cells or inappropriate killing of vital cells underlie a multitude of disorders, including autoimmunity, degenerative diseases and cancers (reviewed in Hotchkiss et $a l^{3}{ }^{3}$ ). Indeed, defects in apoptosis are now considered to be a hallmark of most, if not all, cancers. ${ }^{4}$ Members of the B-cell lymphoma-2 (Bcl-2) protein family are critical regulators of apoptosis and include three subgroups of proteins that either promote cell survival (e.g., Bcl-2 and $\mathrm{Bcl}-\mathrm{x}_{\mathrm{L}}$ ), initiate cell killing (e.g., Bcl-2interacting mediator of cell death (Bim), p53 upregulated mediator of apoptosis (Puma) or Bcl-2-interacting domain
(Bid)) or activate the effector pathways of apoptosis (Bax, Bak) (Figure 1). Observations in human tumours and studies with genetically modified (transgenic or knock-out) mice have shown that tumourigenesis can be driven by gain-of-function mutations in cell death antagonists (e.g., Bcl-2 overexpression) or loss-of-function mutations in cell death activators (e.g., loss of Bim). These mutations can serve as either initiating (primary) or secondary (propagating) oncogenic events to promote tumour development and progression to metastatic disease. Unfortunately, but not surprisingly, mutations that deregulate apoptotic cell death also render tumour cells refractory to cancer therapeutics. This review provides an overview of the pro-survival subgroup of the Bcl-2 family of proteins and their functions in cell death control, particularly in the context of tumourigenesis and responses of tumour cells to anticancer therapy. The functions of the two pro-apoptotic Bcl-2 subgroups in normal physiology, tumourigenesis and cancer therapy are also discussed.

Bcl-2: Discovery of the First Cell Death Regulator and Its Role in Tumourigenesis

The first insights into the role of apoptosis in tumour development came from cytogenetic analysis of human

\footnotetext{
${ }^{1}$ The Walter and Eliza Hall Institute of Medical Research, Molecular Genetics of Cancer Division, Melbourne, Australia and ${ }^{2}$ Department of Medical Biology, The University of Melbourne, Melbourne, Australia

*Corresponding author: A Strasser, The Walter and Eliza Hall Institute of Medical Research, 1G Royal Parade, Parkville, 3050, Victoria, Australia.

Tel: +61-3-9345-2555; Fax: + 61-3- 9347-0852; E-mail: strasser@wehi.edu.au

${ }^{3}$ Current address: Metabolism Branch, National Cancer Institute/NIH, Bethesda, MD 20892, USA

Keywords: apoptosis; Bcl-2; BH3-only proteins; cancer

Abbreviations: Bcl-2, B-cell lymphoma-2; DLBCL, diffuse large B-cell lymphoma; $\mathrm{E} \mu$, immunoglobulin heavy chain gene enhancer; IgH, immunoglobulin heavy chain; $\mathrm{BH}, \mathrm{Bcl}-2$ homology domain; miR, micro RNA; CLL, chronic lymphocytic leukaemia; BCR, B-cell (antigen) receptor; CML, chronic myeloid leukaemia; AML, acute myeloid leukaemia; RNAi, RNA interference; Smac, second mitochondria-derived activator of caspases; DIABLO, direct IAP-binding protein with low pl; IAP, inhibitor of apoptosis protein; Mcl-1, myeloid cell leukemia sequence 1 (BCL2-related); Bim, Bcl-2-interacting mediator of cell death; Bad, Bcl-- $\mathrm{L} / \mathrm{Bcl}-2$-associated death promoter; Bid, Bcl-2-interacting domain; Puma, p53 upregulated mediator of apoptosis; Bik, Bcl-2-interacting killer; Bmf, Bcl-2-modifying factor; Hrk, Harakiri

Received 29.11.10; revised 10.1.11; accepted 28.1.11; Edited by G Melino; published online 18.3.11
} 


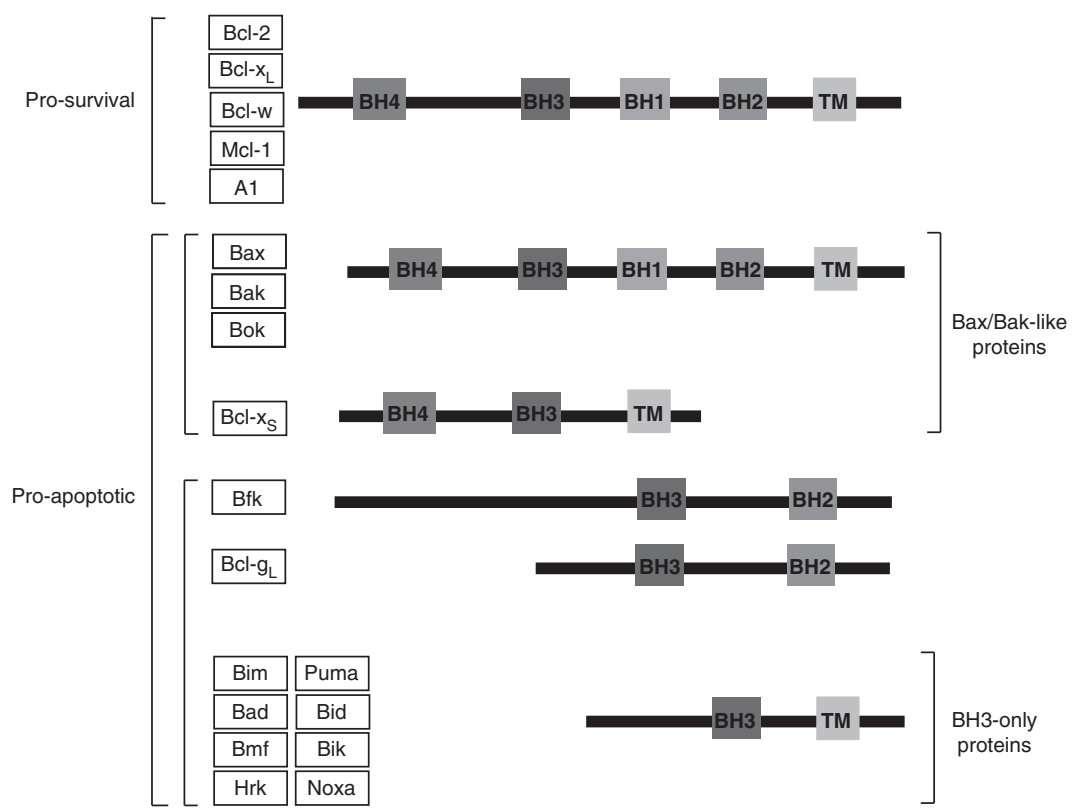

Figure 1 The mammalian Bcl-2 protein family. Bcl-2 family members share regions of homology called Bcl-2 homology (BH) domains, and may contain a trans-membrane (TM) domain that mediates insertion into the outer membrane of the mitochondria and to the endoplasmic reticulum. The pro-survival family members, including Bcl-2, Bcl- $\mathrm{X}_{\mathrm{L}}$, $\mathrm{Bcl}-\mathrm{w}, \mathrm{Mcl}-1$ and $\mathrm{A} 1$, share four $\mathrm{BH}$ (Bcl-2 Homology) domains plus a TM region. The pro-apoptotic family members can be sub-divided into two subgroups: the multi-BH

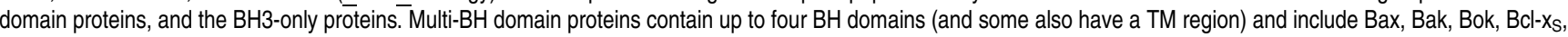
$\mathrm{Bcl}-\mathrm{g}_{\mathrm{L}}$ and Bfk. The BH3-only proteins include Bad, Bik, Bid, Hrk, Bim, Puma, Noxa and Bmf, and are so-called because they contain only the BH3-domain. Some also contain a TM region

B-cell lymphomas. A strong correlation was observed between the $t(14 ; 18)$ chromosomal translocation and human follicular centre B-cell lymphoma. ${ }^{5}$ This rearrangement placed a then novel gene, $b c l-2$, under the control of the immunoglobulin heavy chain $(\mathrm{IgH})$ gene enhancer $\mathrm{E} \mu$. The $b c l-2$ gene was subsequently cloned by three groups from follicular lymphoma cells, a diffuse large B-cell lymphoma (DLBCL) derived cell line and normal tissue,$^{6-10}$ and functional studies with cytokinedependent cell lines showed that enforced expression of $\mathrm{Bcl}-2$ inhibits growth factor deprivation-induced death of these cells but does not enhance their proliferation. ${ }^{11}$ These results showed that the molecular mechanisms that control cell survival and cell proliferation in response to cytokine stimulation must be distinct and demonstrated for the first time that defects in the control of cell death can cause cancer.

The in vivo function of $\mathrm{Bcl}-2$ was first probed by the generation of transgenic mice that were engineered to express $b c l-2$ under control of the IgH gene enhancer $\mathrm{E} \mu$, thereby mimicking the $t(14 ; 18)$ chromosomal translocation characteristic of human follicular centre B lymphoma. Such $\mathrm{E} \mu-b c l-2$ transgenic animals were found to harbour abnormally increased numbers (3- to 5-fold) of B lymphoid cells, a large (30- to 200-fold) excess of antibody forming cells and increased serum Ig levels. ${ }^{12}$ These immune system abnormalities progressed with relatively high incidence (at least on certain genetic backgrounds, such as mixed C57BL/6xSJL) to fatal systemic lupus erythematosus-like autoimmune nephritis, ${ }^{13}$ demonstrating for the first time that apoptosis of lymphocytes imposes a critical barrier against autoimmune disease.

However, despite the marked B lymphoid cell survival advantage conferred by $\mathrm{Bcl}-2$ overexpression, $\mathrm{E} \mu-b c l-2$ transgenic mice displayed only a low incidence of lymphoma at $\sim 5 \%$ within the first year of life. ${ }^{14-16}$ This long latency period indicated that the stochastic acquisition of additional oncogenic mutations was required to promote the transition from low-grade polyclonal hyperplasia to monoclonal highgrade malignancy. Indeed, over half of the plasmacytomas and lymphomas from the $\mathrm{E} \mu-b c l-2$ transgenic mice were found to harbour translocations of the c-myc proto-oncogene into the $\mathrm{IgH}$ gene locus. ${ }^{15,16}$

The transcriptional regulator c-Myc controls a diverse array of target genes that regulate cell cycle progression, cell volume growth, inhibition of terminal differentiation and, under conditions where survival signals are limiting, apoptosis (reviewed in Soucek and Evan ${ }^{17}$ ). Importantly, abnormally high levels of Myc have been observed in $\sim 70 \%$ of all human cancers (reviewed in Soucek and Evan ${ }^{17}$ ). When transgenic mice were engineered to express both myc and $b c l-2$ transgenes $(\mathrm{E} \mu-m y c / E \mu-b c l-2$ doubly transgenic mice), this provided the first formal demonstration that deregulated cell proliferation and impaired cell death were potently synergistic in tumourigenesis (Figure 2, left side). Indeed, $\mathrm{E} \mu-m y c / \mathrm{E}_{\mu}-b c l-2$ bi-transgenic mice displayed marked acceleration in B-cell lymphoma development, and by 7 weeks of age, $100 \%$ of these animals had succumbed to lymphoma compared with only $\sim 40 \%$ of the $\mathrm{E} \mu$-myc single transgenic mice. ${ }^{14}$ In the context of human lymphomagenesis, a similar synergy is seen in human $b c /-2 / \operatorname{lgH}$ follicular lymphoma where progression to a more aggressive state is in some cases associated with the additional acquisition of a c-myc/lgH gene chromosomal translocation. $^{18}$ 

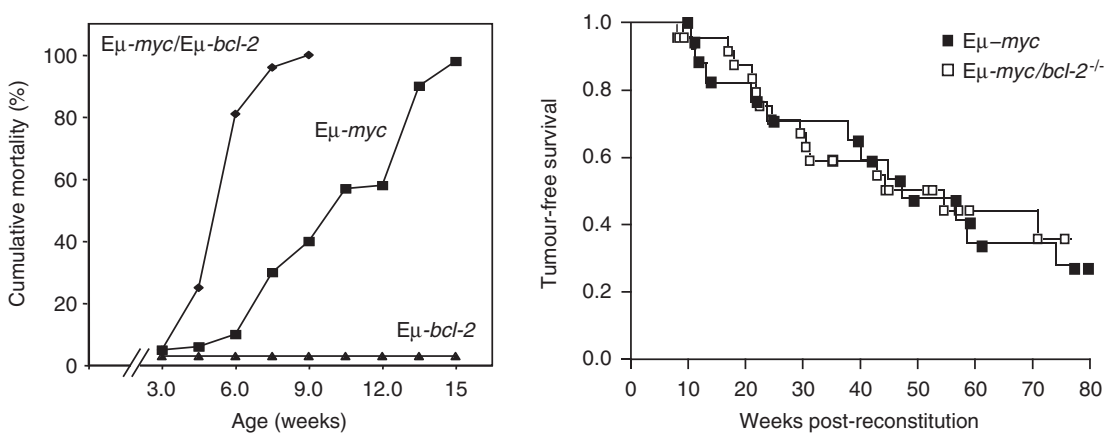

Figure $2 \mathrm{Bcl}-2$ overexpression accelerates $\mathrm{E} \mu$-myc-induced lymphomagenesis but, curiously, loss of endogenous Bcl-2 does not prevent or delay $\mathrm{E} \mu$-myc-induced $\mathrm{B}$ lymphoma development. Left side: Kaplan-Meier analysis of tumour-free survival, comparing $\mathrm{E} \mu$-myc transgenic mice, $\mathrm{E} \mu$-bcl-2 transgenic mice and $\mathrm{E} \mu$-bcl-2/E $\mu$-myc doubly transgenic mice. This figure was first published in A Strasser et al. ${ }^{14}$ and is reproduced here with the permission of the journal. Right side: Kaplan-Meier analysis of tumour latency in lethally irradiated wt (Ly5.1 ${ }^{+}$) mice reconstituted with fetal liver cells from Ly5.2 $2^{+} \mathrm{E} \mu$-myc (closed square), $\mathrm{E} \mu$-myclbcl-2 ${ }^{+/-}$(closed diamond) or $\mathrm{E} \mu$-mycl $b c-2^{-l-}$ (open square) (E14.5) embryos. Mice were killed when deemed moribund by an animal technician who was blinded to the genotype of the mice. This figure was first published in PN Kelly et al. ${ }^{63}$ and is reproduced here with the permission of the journal

\section{The Functions of Pro-Survival Bcl-2 Family Proteins}

The discovery of $\mathrm{Bcl}-2$ established a new paradigm in cancer biology, namely that defects in apoptosis bestow cells with a selective survival advantage, that when combined with mutations that facilitate unrestrained proliferation (e.g., deregulated c-myc expression), can promote malignant transformation. This prompted intense research in this area and with the discovery and cloning of genes encoding prosurvival $\mathrm{Bcl}-\mathrm{x}_{\mathrm{L}},{ }^{19}$ pro-apoptotic $\mathrm{Bax}$ and additional related proteins $^{20}$ it soon became clear that $\mathrm{Bcl}-2$ is a member of a substantial family of apoptosis regulatory proteins, which contains a subgroup that inhibit cell death and two that promote cell killing. ${ }^{21}$ So far, five pro-survival members have been identified in mammals: Bcl-2, Bcl- $\mathrm{x}_{\mathrm{L}}$, myeloid cell leukemia sequence 1 (BCL2-related) (Mcl-1), Bcl-w and $\mathrm{A} 1 / \mathrm{Bfl}-1$ (Figure 1). These proteins share in common four $\mathrm{Bcl}-2$ homology domains (BH1-BH4) and very similar 3D structure (reviewed in Youle and Strasser ${ }^{22}$ ). Overexpression of any one of these proteins is sufficient to protect cells from the effects of a broad range of apoptotic stimuli in culture and even within the whole animal (reviewed in Youle and Strasser ${ }^{22}$ ). Conversely, loss of $\mathrm{Bcl}-2$-like pro-survival proteins has profound consequences on normal tissue homeostasis and development (reviewed in Youle and Strasser ${ }^{22}$ ). For example, Bcl-2 was found to be critical for the survival of renal epithelial stem cells during embryogenesis, melanocyte progenitors and mature $\mathrm{B}$ and T lymphocytes. ${ }^{23,24} \mathrm{Bcl}-\mathrm{x}_{\mathrm{L}}$ on the other hand is critical for survival of erythroid progenitors and neuronal cells during embryogenesis, ${ }^{25}$ whereas Bcl-w appears to have a selective role in spermatogenesis. ${ }^{26}$ Studies with complete and tissue restricted 'knock-out' mice have shown that Mcl-1 is essential for implantation during early development, ${ }^{27}$ survival of haematopoietic stem cells, committed lymphoid progenitors, mature $B$ and $T$ lymphocytes, activated germinal centre B cells and several other cell types. ${ }^{28,29}$ This broad array of defects caused by loss of Mcl-1, its somewhat divergent structure compared with its prosurvival relatives and its rapid turnover ( $\sim 30 \mathrm{~min}$ compared with $\sim 24 \mathrm{~h}$ for $\mathrm{Bcl}-2$ ) indicate that $\mathrm{Mcl}-1$ may have a special role in the control of cell survival. The overall function of $A 1$ in cell survival has not yet been determined because there are four a1 genes in mice that although closely located, are interspersed with other genes, making it challenging to generate mice deficient for all A1 proteins. However, loss of one A1 protein, A1a, was shown to accelerate apoptosis of granulocytes and allergen-activated mast cells. ${ }^{30}$

\section{The Role of Pro-Survival Bcl-2 Family Proteins in Tumourigenesis}

With respect to tumourigenesis, deregulated expression of $\mathrm{Bcl}-2$ and related pro-survival proteins has been found to be a feature of many human cancers, and there is substantial evidence that deregulated expression of $\mathrm{Bcl}-2$-like proteins as either a primary or secondary oncogenic event is critical in tumour development, maintenance and therapeutic resistance (reviewed in Adams and Cory ${ }^{31}$ ).

Bcl-2. As mentioned above, Bcl-2 is overexpressed in human follicular centre B-cell lymphoma as a consequence of the $t(14 ; 18)$ chromosomal translocation. ${ }^{5-10}$ In addition, high levels of $\mathrm{Bcl}-2$ were also detected in significant numbers of chronic lymphocytic leukaemia (CLL), DLBCL and mantle cell lymphoma. ${ }^{32-34}$ High levels of $\mathrm{Bcl}-2$ expression are not restricted to haematological malignancies, but were also reported for certain solid tumours, including those of the brain, breast and lung. ${ }^{35,36}$ The upregulation of BCl-2 in CLL and certain other cancers has been ascribed to hypo-methylation of the $b c l-2$ promoter $^{32}$ or, possibly more importantly due to hemizygous or homozygous loss of the micro RNAs (miRs) $15 \mathrm{a}$ and $16-1$ (13q14.3 in $\sim 65 \%$ of CLLs) that negatively regulate Bcl-2 (Calin et $a l^{37}$ and Cimmino et $a l^{38}$ ).

Bcl- $\mathbf{x}_{\mathrm{L}}$. Human multiple myelomas have been found to express high levels of $\mathrm{Bcl}-\mathrm{x}_{\mathrm{L}}{ }^{39}$ (and also Mcl-1 (Zhang et $\mathrm{al}^{40}$ ); see below), but comparatively low levels of $\mathrm{Bcl}-2$. $\mathrm{BCl}-\mathrm{x}_{\mathrm{L}}$ has been proposed to promote the survival of follicular and germinal centre B cells undergoing Ig class switch recombination and somatic hypermutation of the variable 
regions of their rearranged Ig genes. ${ }^{41}$ These cells are the likely targets for impaired DNA double-strand break repair that may generate chromosomal translocations, such as those involving the myc oncogene. Deregulated Myc expression is a consistent feature of plasma cell neoplasms in humans (multiple myeloma). ${ }^{42}$ Accordingly, enforced expression of both Myc and Bcl- $\mathrm{x}_{\mathrm{L}}$ under control of the $\mathrm{IgH}$ gene enhancer $(\mathrm{E} \mu$ ) leads to development of plasmacytoma with considerably higher incidence and more rapid onset compared with mice expressing either $\mathrm{Myc}$ or $\mathrm{Bcl}-\mathrm{x}_{\mathrm{L}}$ transgenes alone. ${ }^{42} \mathrm{Bcl}-\mathrm{x}_{\mathrm{L}}$ has also been implicated in the development and therapeutic resistance of $\mathrm{Bcr} / \mathrm{Abl}^{+}$chronic myelogenous leukaemia. ${ }^{43}$ A broad range of signalling pathways are activated by the $\mathrm{Bcr} /$ Abl oncogenic tyrosine kinase, and the STAT5 transcription factor, an activator of $b c l-x$ transcription, is known to have a major role in cellular transformation. ${ }^{43}$ Pertinently, somatically acquired copy number increases in $b c l-x$ have been found in a range of human cancers, including certain lung cancers and giant-cell tumours of the bone. ${ }^{44}$

Mcl-1. Mcl-1 (myeloid cell leukaemia 1) was identified as an early response gene induced during the differentiation of ML-1 human myeloblastic leukaemia cells ${ }^{45}$ and has since been shown to be expressed at relatively high levels in a broad range of both haematological as well as solid malignancies, including multiple myeloma, acute myeloid leukaemia (AML) and cholangiocarcinomas. ${ }^{46,47}$ Transgenic mice expressing $\mathrm{Mcl}-1$ under the control of the endogenous $\mathrm{mcl}-1$ promoter display enhanced survival of $B$ and $T$ cells, and develop myeloid malignancy, albeit with low incidence and long latency. ${ }^{48}$ Expression of $\mathrm{mcl}-1$ under control of the panhaematopoietic vav promoter elicited transformation of immature haematopoietic stem/progenitor and pre-B/B lymphoid cells. ${ }^{49}$ Moreover, enforced expression of $\mathrm{Mcl}-1$ was shown to inhibit Myc-induced apoptosis and therefore synergised with an $\mathrm{E} \mu-m y c$ transgene in lymphomagenesis. ${ }^{49,50}$ A study of 151 clinical isolates of non-Hodgkin's B lymphoma found that high levels of Mcl-1 expression correlated with increasing grade of severity in follicular lymphoma. ${ }^{51}$ Interestingly, the $\mathrm{BH} 3$ mimetic $\mathrm{ABT}-737$, which binds and inhibits $\mathrm{Bcl}-2, \mathrm{Bcl}-\mathrm{x}_{\mathrm{L}}$ and $\mathrm{Bcl}-\mathrm{w}$, but not $\mathrm{Mcl}-1$ or $\mathrm{A} 1$ (see also below), ${ }^{52}$ was unable to inhibit proliferation of B-cell lymphomas or AMLs expressing high levels of Mcl-1 as a single agent, but was highly efficient when $\mathrm{Mcl}-1$ was inactivated, for example by RNA interference (RNAi)mediated knock-down. ${ }^{53,54}$ Recently, somatically acquired copy number increases in $\mathrm{mcl}-1$ have been found in certain lung and breast cancers and, importantly, studies using RNAi have shown that in cell lines derived from some of these tumours, Mcl- 1 is critical for sustained survival and growth, at least in vitro. ${ }^{44}$ Collectively, these results provide evidence that for many malignant cell types Mcl-1 may be critical for sustained survival and expansion and appears to impose an important obstacle against anticancer therapy.

A1/Bfl-1. A1 (the murine homologue of human Bfl-1) is expressed in a broad range of haematopoietic cell populations, including $\mathrm{B}$ and $\mathrm{T}$ lymphocytes, macrophages, neutrophils, mast cells and dendritic cells. ${ }^{55}$ In many (possibly all) of these cells, A1 expression is rapidly induced by activation of antigen or cytokine receptors (e.g., $\mathrm{B}$-cell (antigen) receptor (BCR), T-cell (antigen) receptor, receptor that binds the constant region of $\mathrm{lgE}$ ) but $\mathrm{A} 1$ levels also rapidly decline because of its rapid turnover. ${ }^{30}$ Molecular profiling of B-cell lymphomas has indicated that A1 overexpression may be a signature of certain $B$ lymphoid malignancies ${ }^{56}$ and may therefore constitute a target for the design of novel anticancer therapeutics. Indeed, downregulation of $\mathrm{A} 1$ expression using short hairpin RNAs was found to increase the sensitivity of $B$ lymphoblastic cells and DLBCL lines to anti-CD20 (Rituximab)-mediated killing and conventional chemotherapeutic agents, including doxorubicin, cisplatin and vincristine. ${ }^{57} \mathrm{~A} 1$ has also been implicated in the development of $\mathrm{Bcr} / \mathrm{Abl}^{+}$chronic myeloid leukaemia $(\mathrm{CML})$, as $\mathrm{A} 1$ upregulation was reported to be essential to promote cell cycle transition, IL-3-independent growth and in vivo leukaemic transformation. ${ }^{58}$

Bcl-w. Although high levels of Bcl-w expression have not to date been reported for haematological malignancies, Bcl-w overexpression has been found to promote survival and influence the migratory and invasive potential of gastric cancer cells. ${ }^{59}$ This study also found that Bcl-w, but not $\mathrm{Bcl}-2$ overexpression, correlated with increased levels of matrix metalloproteinase-2, an enzyme that catalyses the destruction of the basement membrane to facilitate metastasis. Moreover, Bcl-w was also reported to be frequently expressed at relatively high levels in colorectal adenocarcinomas (69/75 tumours) with higher Bcl-w levels detected in advanced stage cancers as opposed to localised tumours with better prognosis. ${ }^{60}$

\section{Which Endogenous Bcl-2-Like Pro-Survival Protein(s) Is/Are Required for the Development and Sustained Growth of Tumour Cells?}

Only a small subset of cancers (e.g., human follicular centre B lymphoma) have the chromosomal translocations that activate massive overexpression of pro-survival Bcl-2 family members. It therefore appears likely that expression of pro-survival $\mathrm{Bcl}-2$ family members under control of their endogenous regulatory elements is critical to keep cells alive during the process of neoplastic transformation and may also be essential to sustain the survival and growth of malignant cancers. Knowing which pro-survival Bcl-2-like protein(s) is/are critical in which type of tumour will undoubtedly provide vital clues for the development novel cancer therapies. Initial insight was provided from studies with mice harbouring a doxycyline-repressible $b c l-2$ transgene and a constitutive c-myc transgene. As expected, mice that constitutively expressed both Myc and Bcl-2 transgenes developed lymphoblastic leukaemia with high incidence. Remarkably, shut-down of the inducible bcl-2 transgene (by administration of doxycycline to the drinking water) in lymphomaburdened bi-transgenic mice resulted in tumour regression and significantly prolonged animal survival in many (although not all) cases. ${ }^{61}$ These findings demonstrate that sustained $\mathrm{Bcl}-2$ overexpression is required for the continued growth of lymphomas that were elicited (in part) by $\mathrm{Bcl}-2$ overexpression. But what about tumours that were not elicited by enforced overexpression of $\mathrm{Bcl}-2$ or one of its pro-survival relatives? In this regard, our 
group recently carried out the first study to address the role of endogenous Bcl-2 in tumourigenesis. As Bcl-2 is expressed in many $B$ lymphoid cell subsets, including early progenitors ${ }^{62}$ and as Bcl-2 overexpression enhances survival of B lymphocytes at all stages of development, ${ }^{12}$ we hypothesised that endogenous $\mathrm{Bcl}-2$ may be critical for $\mathrm{E} \mu-m y c$-induced lymphomagenesis.

Although Bcl-2-deficient mice complete embryonic development, they succumb to polycystic kidney disease between 3 and 5 weeks of age ${ }^{23,24}$ prohibiting long-term studies on lymphoma development in $b c /-2^{-1-}$ mice expressing an $\mathrm{E} \mu$-myc transgene. We overcame this impediment by reconstituting lethally irradiated wild-type mice with an $\mathrm{E} \mu-\mathrm{myc} / \mathrm{bcl}-2^{-1-}$ or, as controls, an $\mathrm{E} \mu-m y c / b c l-2^{+1+}$ (referred hereafter as $\mathrm{E} \mu-m y c$ ) haematopoietic system. Analysis of the sequential stages of B-cell development in pre-leukaemic $\mathrm{E} \mu-m y c / b c l-2^{-l-}$ mice revealed that endogenous $\mathrm{Bcl}-2$ was largely dispensable in pro-B, pre-B and immature (slgM ${ }^{\mathrm{hi}} \mathrm{slgD}^{\mathrm{lo}}$ ) $B$ cells, but was critical for the survival of mature $B$ cells, as the $\mathrm{E} \mu-m y c / b c l-2^{-1-}$ reconstituted mice were almost completely devoid of slgM ${ }^{\mathrm{lo}}$ slg $\mathrm{D}^{\mathrm{hi}} \mathrm{B}$ lymphocytes in their spleen and lymph nodes. ${ }^{63}$ Surprisingly, despite the abnormal B-cell deficit, the absence of $b c /-2$ did not reduce the incidence or delay the onset of $\mathrm{E} \mu$-myclymphoma (Figure 2, right side). ${ }^{63}$ These findings indicate that during the genesis of Myc-driven lymphoma, the acquisition of oncogenic lesions that propagate neoplastic transformation must occur at a stage at which Bcl-2 is dispensable for survival. The pro-B and/or pre-B cells (or perhaps earlier progenitors), but not the mature $B$ lymphocytes, are likely candidates because $\mathrm{Bcl}-2$ is not critical for their survival. Pertinently, pro-B and pre-B cells are subject to genomic instability because of $\mathrm{lgH}$ and $\mathrm{lgL}$ gene rearrangement, which are error prone processes that can cause oncogenic lesions. As impaired apoptosis is widely accepted to be an essential step in tumour development, ${ }^{4}$ these results also raise the possibility that one or more pro-survival protein(s), other than $\mathrm{Bcl}-2$, is/are critical to sustain cell survival during the course of Mycinduced lymphomagenesis (Figure 3 ). $\mathrm{Bcl}-\mathrm{x}_{\mathrm{L}}$ and $\mathrm{Mcl}-1$ represent attractive candidates because they are expressed at several stages of $B$ lymphopoiesis (Figure 4$)^{41}$ and both have been shown to be critical for the survival of $B$ lymphoid progenitors and/or precursors. ${ }^{25,28}$ Moreover, as mentioned above, overexpression of $\mathrm{Bcl}-\mathrm{x}_{\mathrm{L}}$ or $\mathrm{Mcl}-1$ can cause lymphoid malignancies ${ }^{49,64}$ and synergises with Myc in lymphomagenesis. ${ }^{42,49}$

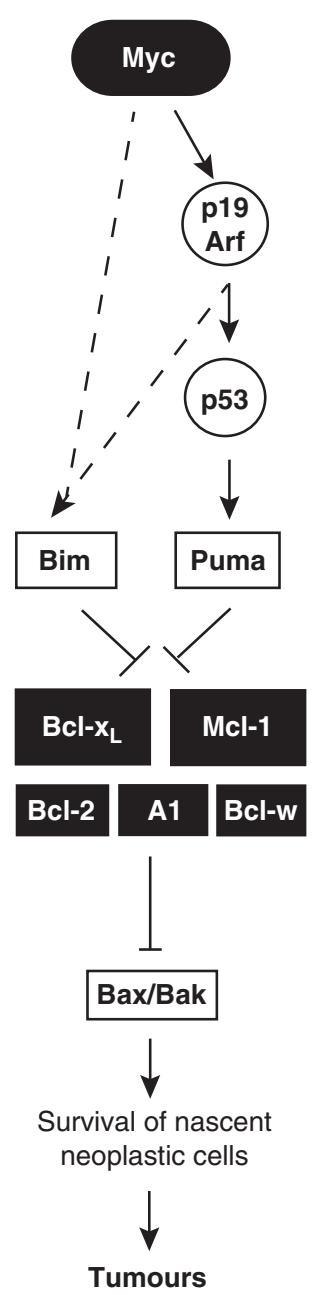

Figure 3 Proposed model for apoptosis induced by deregulated Myc expression with consequent suppression of Myc-induced lymphomagenesis. Two major apoptotic pathways contribute to the suppression of Myc-induced tumourigenesis, one involving p19Arf-p53-mediated activation of the BH3-only protein Puma, and the other involving apoptosis mediated by BH3-only relative Bim. The mechanisms by which Myc activates Bim expression are presently unclear. As pro-survival Bcl-2 family members are thought to be essential for the initiation of Myc-induced lymphoma development and as Bcl-2 was shown to be dispensable for this, we predict that $\mathrm{Bcl}-\mathrm{x}_{\mathrm{L}}$ and $\mathrm{Mcl}-1$ stand at the convergence point of these two pathways, possibly by keeping Bim and Puma in check

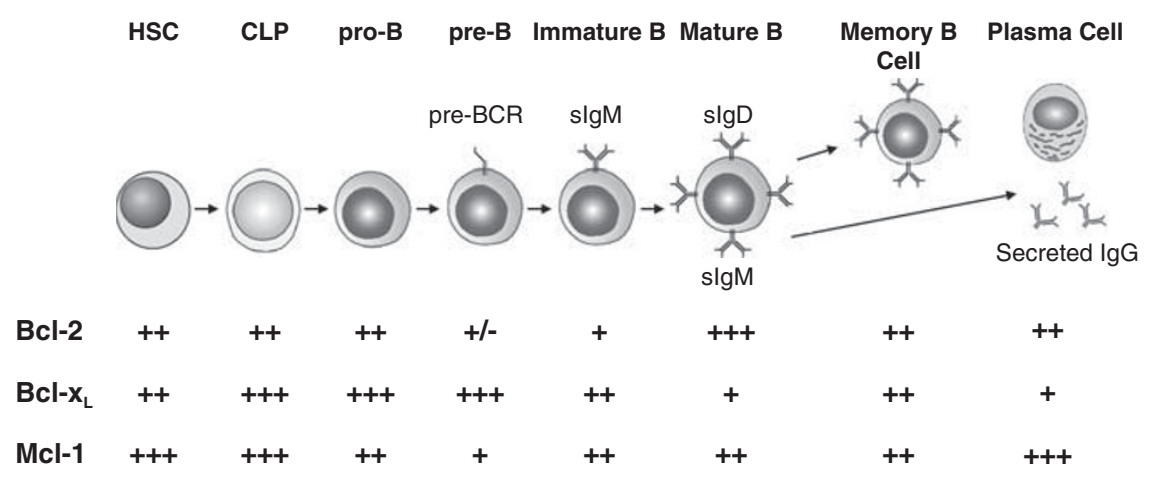

Figure 4 Expression of Bcl-2, Bcl- $x_{L}$ and Mcl-1 during B lymphocyte differentiation. The levels of expression of Bcl-2, Bcl- $x_{L}$ and Mcl-1, based on published date (see papers cited in the text) during $B$ lymphocyte differentiation in the mouse are indicated 
The demonstration that removing $\mathrm{Bcl}-2$ decimated the lymphomas arising in $\mathrm{E} \mu-m y c /$ inducible $\mathrm{E} \mu-b c l-2$ doubly transgenic mice ${ }^{61}$ supports the concept that inactivation of Bcl-2 constitutes a promising new approach to cancer therapy. ${ }^{52}$ However, our finding that endogenous $\mathrm{Bcl}-2$ is dispensable for $\mathrm{E} \mu-m y c$-induced lymphoma development ${ }^{63}$ may also indicate that distinct pro-survival Bcl-2 family proteins may have to be targeted for treatment of different tumour types.

\section{Bax/Bak Proteins: Essential Activators of the Effector Phase of Apoptosis}

Pro-survival Bcl-2 family members maintain cell survival (at least in part) by keeping in check the so-called pro-apoptotic multi-BH domain $\mathrm{Bcl}-2$ family members Bax, Bak (and possibly also the poorly studied Bok) (reviewed in Youle and Strasser ${ }^{22}$ ). These proteins contain three $\mathrm{BH}$ domains and share with their pro-survival relatives surprisingly extensive structural similarity. Activation of Bax and Bak involves homo-dimerisation and oligomerisation within the outer mitochondrial membrane, which leads to release of apoptogenic proteins, such as cytochrome $c$ and second mitochondria-derived activator of caspase (Smac)/ direct IAP-binding protein with low pl (DIABLO), from the mitochondrial inter-membrane space (reviewed in Chipuk and Green ${ }^{65}$ ). This in turns promotes activation of the caspase cascade that culminates in proteolysis of hundreds of intracellular proteins and consequent cellular demolition (Figure 5). Bax and Bak appear to have largely overlapping function. Mice lacking Bak appear normal ${ }^{66}$ and those lacking Bax have a minor increase in spleen weight and the males are sterile because Bax-dependent death of early stem cells in the testes are required to initiate spermatogenesis. ${ }^{67}$ Remarkably, Bax/Bak doubly deficient mice have severe developmental defects, including webbed feet, and cells from these animals are highly resistant to a broad range (possibly all) stimuli that activate the so-called Bcl-2-regulated (also called 'mitochondrial', 'intrinsic' or 'stress') apoptotic pathway, ${ }^{66}$ even enforced overexpression of $\mathrm{BH} 3$-only proteins. ${ }^{68,69}$ In mouse model systems, such as $\mathrm{E} \mu-m y c$ transgenic mice, Bax loss can accelerate tumourigenesis, ${ }^{70}$ but loss of Bax or Bak has so far only rarely been observed in human cancer, most likely because they have overlapping function and hence four alleles would need to be inactivated in nascent neoplastic cells, which would be exceedingly rare. Given that combined loss of Bax and Bak potently protects diverse cell types against a broad range of apoptotic stimuli, ${ }^{66,71}$ one may expect that $\mathrm{bax}^{-1-} \mathrm{bak}^{-1-}$ mice would be highly predisposed to tumour development. No reports to this effect have been published to our knowledge. This may likely be explained by the fact that insufficient numbers of these animals could be observed long-term for tumour development because most of them die soon after birth ${ }^{66}$ and the few survivors develop severe lymphadenopathy and autoimmune disease that curtails their lifespan. ${ }^{71}$ Intriguingly, somatically acquired copy number variations in the bax/bak related, but less well studied, gene bok have been found in certain human cancers, ${ }^{44}$ indicating that it may function as a tumour suppressor.

\section{BH3-Only Proteins: Essential Initiators of Apoptosis that can Function as Tumour Suppressors}

Apoptosis is initiated in response to a broad range of stress stimuli, including those frequently encountered during tumour development, such as oncogene activation, DNA damage, hypoxia (oxygen deprivation), loss of appropriate growth signals and anoikis (loss of cell attachment) (Figure 6; reviewed in Youle and Strasser ${ }^{22}$ ). BH3-only proteins (Bim, Puma, Bid, Bcl- $x_{\mathrm{L}} / \mathrm{Bcl}-2$-associated death promoter (Bad), Bcl-2-interacting killer (Bik), Noxa, Bcl-2-modifying factor (Bmf), Harakiri (Hrk)), a pro-apoptotic subgroup of the Bcl-2 family that share with each other and the family at large only the $\sim 23$ aa $\mathrm{BH} 3$ domain are essential for initiation of apoptosis signalling (reviewed in Huang and Strasser ${ }^{72}$ ). $\mathrm{BH} 3-$ only proteins trigger apoptosis by binding via their $\mathrm{BH} 3$ region to a groove on the surface of their pro-survival relatives, thereby unleashing Bax and Bak, but at least some of them have also been reported to directly bind and activate Bax/Bak (reviewed in Youle and Strasser ${ }^{22}$ ). Studies with genetargeted mice have shown that different apoptotic stimuli require distinct $\mathrm{BH} 3-$ only proteins for cell killing (reviewed in Huang and Strasser ${ }^{72}$ ). For example, Puma is essential for p53-mediated apoptosis induced by DNA damage, anoxia or Myc overexpression, ${ }^{73,74}$ whereas Bim is critical for growth factor deprivation, ER stress and deregulated calcium fluxinduced killing in diverse cell types. ${ }^{75,76}$ Several studies have shown that $\mathrm{BH}$-only proteins can exert overlapping functions in cell killing. For example, cells lacking both of the p53activated BH3-only proteins Puma and Noxa are more resistant to DNA damage induced (i.e., p53-mediated) apoptosis than those lacking only Puma and indeed as refractory as p53-deficient ones. ${ }^{77}$ Moreover, combined loss of Bim and Puma renders a broad range of cell types more resistant to cytokine deprivation and certain other apoptotic stimuli than loss of either BH3-only protein alone, ${ }^{78,79}$ indeed almost as resistant as combined loss of Bax and Bak. ${ }^{66}$

BH3-only proteins function as crucial barriers against the development of malignant disease by serving as molecular sentinels to kill abnormal cells harbouring potentially neoplastic lesions (reviewed in Huang and Strasser ${ }^{72}$ ). Accordingly, loss of either Bim ${ }^{80}$ or Puma, ${ }^{81,82}$ two key initiators of cytokine withdrawal induced apoptosis, ${ }^{75}$ inhibit the apoptosis of Myc-overexpressing B cells and accelerates $\mathrm{E} \mu$-myc-induced lymphomagenesis. Importantly, loss of both alleles of bim has been found in $\sim 20 \%$ of human mantle cell B lymphoma ${ }^{83}$ and $\sim 40 \%$ of Burkitt lymphomas express only very low levels of Puma, which in (at least) some cases is thought to be due to epigenetic silencing. ${ }^{81}$ Moreover, somatically acquired loss of copy number for puma was found in a range of human cancers. ${ }^{44}$ Collectively, these results show that pro-apoptotic $\mathrm{BH} 3-$ only $\mathrm{Bcl}-2$ family members can function as tumour suppressors.

\section{Two Models to Explain the Functional Interactions between the Three Bcl-2 Family Subgroups}

$\mathrm{BH} 3-$ only proteins and the $\mathrm{BH} 3$ domains from multi- $\mathrm{BH}$ domain pro-apoptotic Bax/Bak bind and occupy the hydrophobic groove on the surface of their pro-survival relatives, 


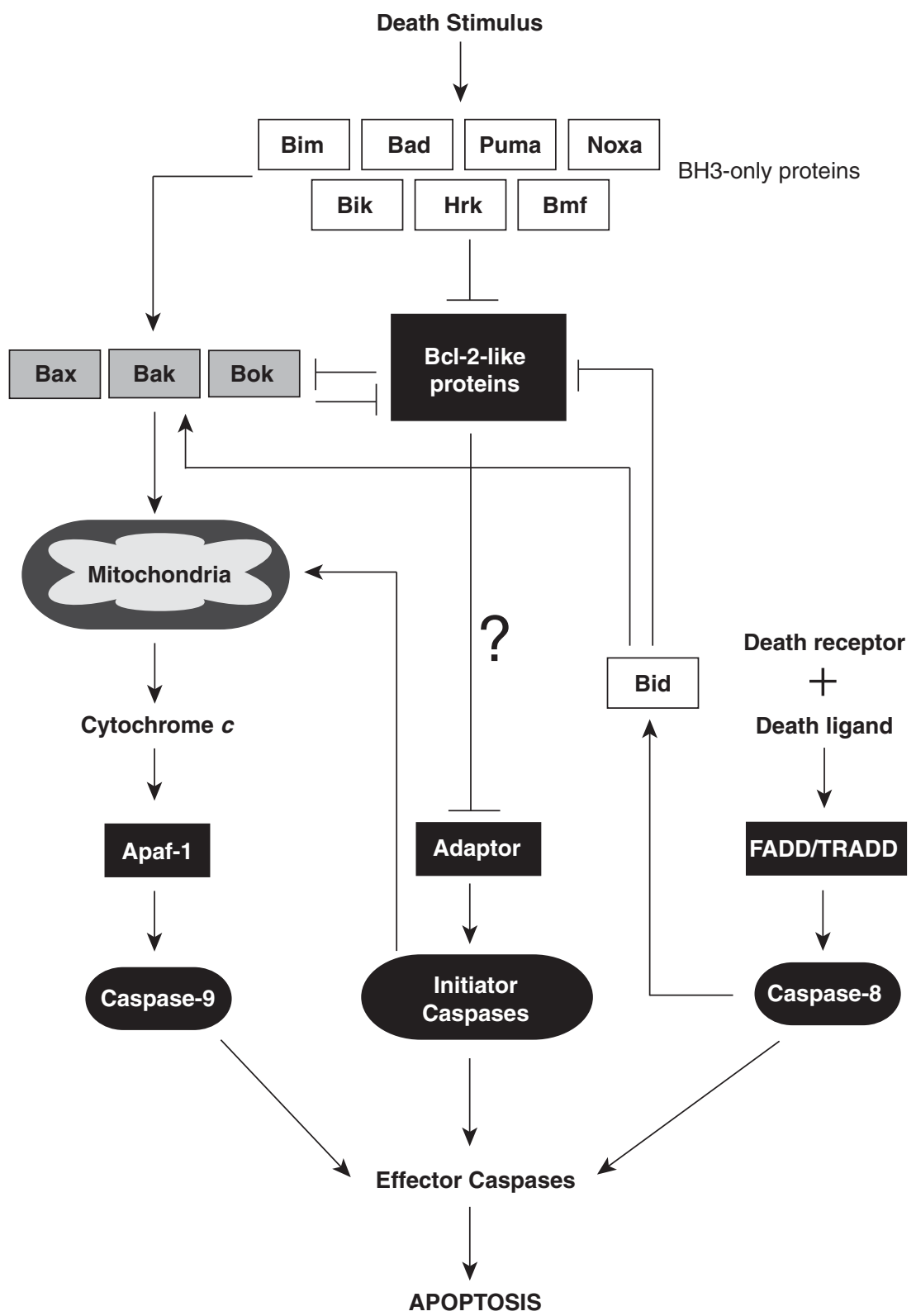

Figure 5 Mammals have two distinct but ultimately converging pathways to apoptosis. Signalling via death receptors is indicated on the right. The 'death receptor' pathway is activated by the stimulation of extracellular 'death receptors' (such as, Fas/CD95) by their cognate 'death ligands' (FasL/CD95L). The adaptor protein FADD then promotes recruitment and activation of the 'initiator caspase', caspase-8. Caspase-8 in turn proteolytically activates 'effector caspases' (caspase-3, -6 and -7 ). Caspase-8-mediated proteolytic activation of the BH3-only protein Bid connects the 'death receptor' pathway to the 'Bcl-2 regulated' pathway and serves to amplify the apoptosis cascade. This amplification mechanism is essential for Fas-induced killing in so-called type 2 cells (e.g., hepatocytes) but dispensable in type 1 cells (e.g., thymocytes). The Bcl-2-regulated pathway is indicated on the left, and is activated in response to a broad range of cell stressors, such as growth factor deprivation or chemotherapeutic drugs. The pro-apoptotic $\mathrm{BH} 3-0 n l y$ proteins (members of the Bcl-2 family; red boxes) serve as molecular sensors to initiate apoptosis in response to these cellular stresses. Their ability to kill cells is dependent on the multi-BH domain pro-apoptotic Bax/Bak-like Bcl-2 family members. BH3-only proteins are thought to activate Bax/Bak either directly or indirectly by unleashing them from the pro-survival Bcl-2 family members. Regardless of mode of activation, activated Bax/Bak cause permeabilisation of the mitochondrial outer membrane (MOMP) with consequent release of apoptogenic factors (e.g., cytochrome $c$, Smac/DIABLO). Together with the adaptor protein Apaf-1, cytochrome $c$ promotes activation of the 'initiator caspase', caspase-9 that in turn leads to 'effector caspase' activation and subsequent cell demolition. The colour reproduction of this figure is available on the html full text version of the manuscript

such as $\mathrm{Bcl}-\mathrm{x}_{\mathrm{L}}$ (formed by their $\mathrm{BH} 1 \mathrm{BH} 2$ and $\mathrm{BH} 3$ domains). ${ }^{84,85}$ This physical interaction has been shown to be dependent on a functional $\mathrm{BH} 3$ domain within the $\mathrm{BH}$-only protein. It was originally believed that all pro-survival $\mathrm{Bcl}-2$ family members have identical biochemical action. It has, however, been discovered that they differ markedly with respect to their binding affinities for different BH3-only proteins. $^{86,87}$ Bim, Puma and caspase activated Bid (tBid) (so-called promiscuous $\mathrm{BH} 3$-only proteins) bind with high affinity to all pro-survival $\mathrm{Bcl}-2$ family members, whereas in 


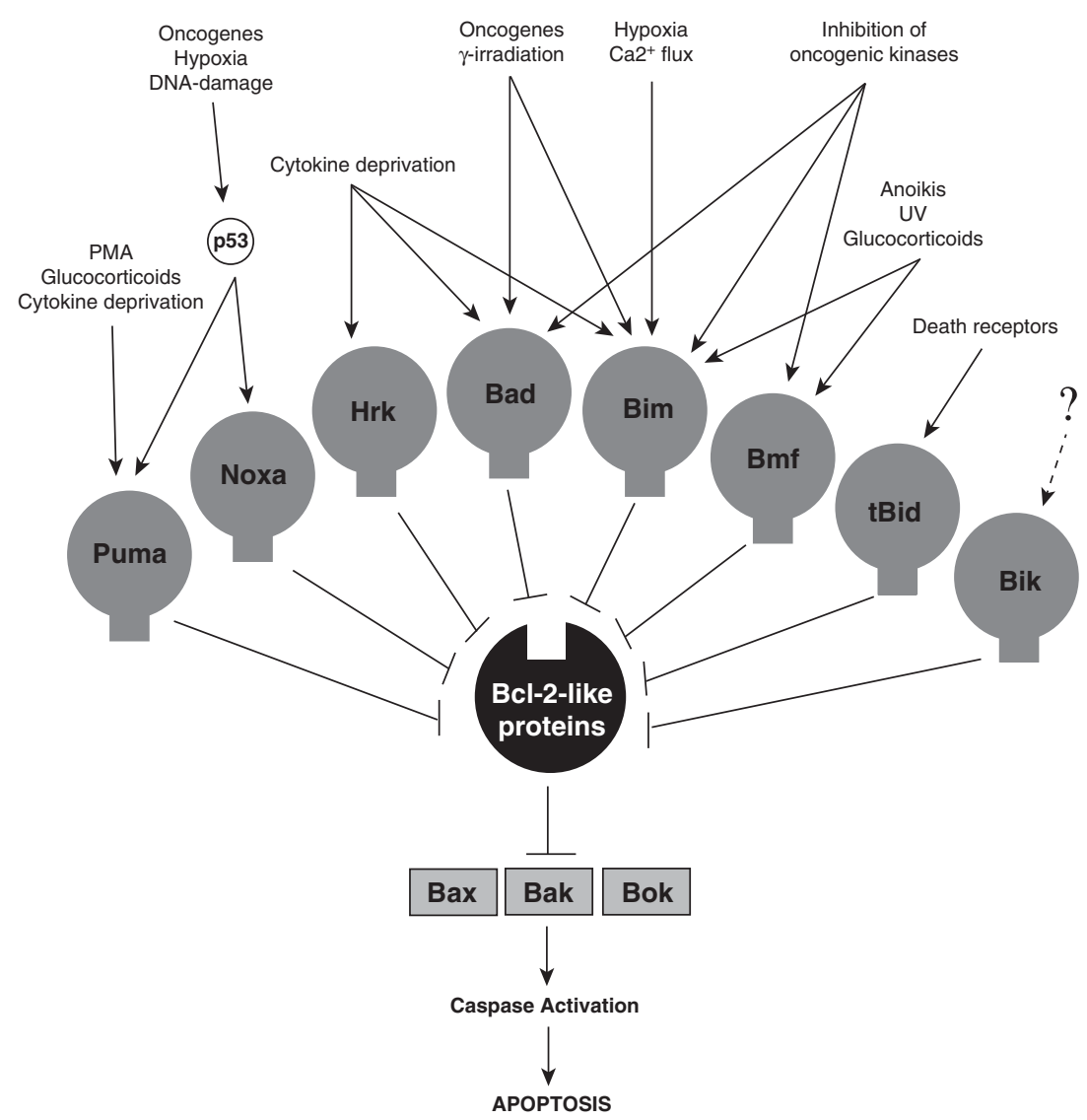

Figure 6 Activation of BH3-only proteins by distinct apoptotic stimuli including those elicited by oncogene activation. Different apoptotic stimuli, including oncogene activation, DNA damage, hypoxia (oxygen deprivation), loss of appropriate growth signals and anoikis (loss of cell attachment), initiate apoptosis signalling by activating different BH3-only proteins. Some apoptotic stimuli activate more than one BH3-only protein (e.g., cytokine deprivation can activate both Bim and Puma). Also, there are cell type-specific differences (e.g., Puma is more important than Bim in cytokine deprivation-induced apoptosis in mast cells, whereas Bim is more important than Puma in lymphoid cells)

striking contrast, all other (so-called selective) BH3-only proteins bind only a subset. For example, Bad binds to $\mathrm{Bcl}-2, \mathrm{Bcl}-\mathrm{x}_{\mathrm{L}}$ and $\mathrm{Bcl}-\mathrm{w}$ but not to $\mathrm{Mcl}-1$ or $\mathrm{A} 1$, whereas Noxa interacts strongly with $\mathrm{Mcl}-1$ and $\mathrm{A} 1$ but not with $\mathrm{Bcl}-2, \mathrm{Bcl}-\mathrm{x}_{\mathrm{L}}$ or Bcl-w. ${ }^{86,87}$ These observations provide an explanation for why enforced expression of either Bim, Puma or tBid on their own potently kills cells whereas, for example, enforced Bad or Noxa expression alone do not. ${ }^{86,87}$ Interestingly, co-expression of 'selective' BH3-only proteins with complementary binding patterns (e.g., Bad plus Noxa) can kill cells as potently as Bim or Puma. ${ }^{86,87}$ Two models have been proposed to explain the functional interactions between the pro-survival $\mathrm{Bcl}-2$ family members, pro-apoptotic $\mathrm{BH} 3-$ only proteins and Bax/Bak. The 'direct' model predicts that $\mathrm{BH}$-only proteins exist as either 'activators' or 'derepressors'. Bim and tBid (and according to one study perhaps also Puma) represent activator proteins and can initiate apoptosis by directly binding to Bax and/or Bak. ${ }^{87}$ Bim and tBid can also be bound and thereby be kept in check by pro-survival Bcl-2-like proteins. ${ }^{88,89}$ Thus, the 'derepressor' $\mathrm{BH} 3$-only proteins, promote apoptosis by binding to the pro-survival Bcl-2 family members, thereby liberating Bim, tBid and Puma to activate Bax/Bak. ${ }^{87,90}$
Conversely, according to the 'indirect' model BH3-only proteins do not bind and directly activate Bax and/or Bak. Instead, it proposes that in healthy cells Bax and Bak are kept in check by the pro-survival Bcl-2 family members and the binding of $\mathrm{BH} 3-$ only proteins to the pro-survival $\mathrm{Bcl}-2$ family members unleashes Bax/Bak. ${ }^{91,92}$ Thus, for apoptosis initiation all pro-survival $\mathrm{Bcl}-2$ family members present in a cell must be neutralised by $\mathrm{BH} 3-o n l y$ proteins.

It has recently been reported that cells lacking Bim, Puma and Bid are highly resistant to a broad range of apoptotic stimuli, ${ }^{93}$ Their resistance was, however, no greater than that afforded by combined loss of Bim and Puma, ${ }^{78}$ and because bim $^{-1-}$ puma ${ }^{-1-}$ bid $^{-1-}$ mice ${ }^{93}$ did not show the early perinatal lethality that is highly prevalent in $\mathrm{bax}^{-1-} \mathrm{bak}^{-1-}$ mice, ${ }^{66}$ it remains questionable whether Bim, Puma and Bid are, as proposed, ${ }^{93}$ the sole $\mathrm{BH} 3$-only proteins that can promote Bax/Bak activation (either directly or indirectly). Interestingly, a recent study with knock-in mutant mice in which the $\mathrm{BH} 3$ region of Bim was modified to alter its binding specificity to that of Bad, Noxa or Puma indicated that aspects of both the 'direct' and 'indirect' models may actually operate in developmentally programmed death (at least with respect to Bim). ${ }^{94}$ 


\section{Targeting Pro-Survival Bcl-2 Proteins for Cancer Therapy: An Emerging Strategy for the Management of Malignant Disease}

The ability to trigger tumour cell apoptosis is (at least in part) responsible for the therapeutic effects of chemotherapeutic drugs, $\gamma$-radiation and even novel designer cancer drugs, such as inhibitors of oncogenic kinases. For example, the killing of $\mathrm{E} \mu-m y c$ lymphoma cells by DNA damage inducing chemotherapeutic drugs required, as expected, the p53 targets Puma and Noxa, but surprisingly optimal lymphoma cell killing required in addition the $\mathrm{BH} 3$-only protein $\mathrm{Bim},{ }^{95}$ which is not activated in a p53-dependent manner. Bim is also critical for the killing of tumour cells by inhibitors of oncogenic kinases, such as the response of CML to the BCR-ABL inhibitor Gleevec, ${ }^{96}$ the response of small cell lung cancer cells bearing EGF-R mutations to Gefitinib or Tarceva ${ }^{97-99}$ or the response of $B-$ Raf mutant melanoma and colon carcinoma cells to shut-down of this oncogenic pathway. ${ }^{100}$

As BH3-only proteins are critical for the responses to cancer therapeutics but many cancers have aberrations that preclude optimal induction of these killer proteins (e.g., p53 mutations, $\mathrm{Bcl}-2$ overexpression), small molecule mimetics of $\mathrm{BH} 3-$ only proteins that can directly target pro-survival Bcl-2 family members are being developed as a novel therapeutic approach. One of the most promising candidates is the small molecule $\mathrm{BH} 3$ mimetic $\mathrm{ABT}-737$ and the closely related orally available ABT-263, which were designed to target the hydrophobic groove of $\mathrm{Bcl}-\mathrm{x}_{\mathrm{L}}$, and can also bind Bcl-2 and Bcl-w with very high affinity. ${ }^{52}$ In preclinical studies, ABT-737 promoted tumour regression in murine xeno-transplanation models of certain human lymphomas or small cell lung carcinomas and in primary patient-derived follicular lymphoma cells. ${ }^{52}$ Mechanistic studies indicated that, as expected for a $\mathrm{BH} 3$ mimetic, ABT-737 requires Bax/Bak for cell killing, activating them indirectly by neutralising the pro-survival proteins $\mathrm{Bcl}-2$, $\mathrm{Bcl}-\mathrm{x}_{\mathrm{L}}$ and/or Bcl-w. ${ }^{54}$ Interestingly, it has been found that high levels of $\mathrm{Bcl}-2$ (or other pro-survival $\mathrm{Bcl}-2$ family members) in tumour cells often lead to accumulation of high levels of Bim (and other BH3-only proteins) and that this actually renders them sensitive to ABT-737 because it can both block $\mathrm{Bcl}-2, \mathrm{Bcl}-\mathrm{xL}$ and $\mathrm{Bcl}-\mathrm{w}$ and also liberate the accumulated BH3-only proteins for death duty. ${ }^{101,102}$ Not surprisingly given its selective binding specificity, as a single agent ABT-737 is inefficient at killing tumour cells that express substantial levels of Mcl-1, but it can efficiently kill such cells when combined with other cancer therapeutics. ${ }^{53,54,96}$ Future development and clinical trials of $\mathrm{BH} 3$-mimetics for cancer therapy are therefore awaited with great interest.

\section{Conflict of interest}

The authors declare no conflict of interest.

Acknowledgements. We thank all present and past members of the apoptosis research programs at WEHI, particularly Drs. J Adams, S Cory, D Vaux, D Huang, P Colman, P Bouillet, A Harris, R Kluck and C Scott, for their outstanding contributions. Research in the authors' laboratories is supported by fellowships and grants from the Australian NHMRC (257502, 461299), Cancer Council of Victoria,
NIH (CA 043540), Leukemia and Lymphoma Society (LLS SCOR 7413) and the JDRF/NHMRC (466658).

1. Kerr JFR, Wyllie AH, Currie AR. Apoptosis: a basic biological phenomenon with wideranging implications in tissue kinetics. Br J Cancer 1972; 26: 239-257.

2. Strasser A, O'Connor L, Dixit VM. Apoptosis signaling. Ann Rev Biochem 2000; 69: 217-245.

3. Hotchkiss RS, Strasser A, McDunn JE, Swanson PE. Cell death. N Engl J Med 2009; 361: 1570-1583.

4. Hanahan D, Weinberg RA. The hallmarks of cancer. Cell 2000; 100: 57-70.

5. Tsujimoto Y, Yunis J, Onorato-Showe L, Erikson J, Nowell PC, Croce CM. Molecular cloning of the chromosomal breakpoint of B-cell lymphomas and leukemias with the $\mathrm{t}(11 ; 14)$ chromosome translocation. Science 1984; 224: 1403-1406.

6. Tsujimoto $\mathrm{Y}$, Cossman J, Jaffe E, Croce CM. Involvement of the bcl-2 gene in human follicular lymphoma. Science 1985; 228: 1440-1443.

7. Tsujimoto Y, Finger LR, Yunis J, Nowell PC, Croce CM. Cloning of the chromosome breakpoint of neoplastic $B$ cells with the $t(14 ; 18)$ chromosome translocation. Science 1984; 226: 1097-1099.

8. Cleary ML, Sklar J. Nucleotide sequence of a $t(14 ; 18)$ chromosomal breakpoint in follicular lymphoma and demonstration of a breakpoint-cluster region near a transcriptionally active locus on chromosome 18. Proc Natl Acad Sci USA 1985; 82: 7439-7443.

9. Bakhshi A, Jensen JP, Goldman P, Wright JJ, McBride OW, Epstein AL et al. Cloning the chromosomal breakpoint of $t(14 ; 18)$ human lymphomas: clustering around $J_{H}$ on chromosome 14 and near a transcriptional unit on 18. Cell 1985; 41: 899-906.

10. Cleary ML, Smith SD, Sklar J. Cloning and structural analysis of cDNAs for $b c l-2$ and a hybrid $b c /-2 /$ immunoglobulin transcript resulting from the $t(14 ; 18)$ translocation. Cell 1986; 47: 19-28.

11. Vaux DL, Cory S, Adams JM. Bcl-2 gene promotes haemopoietic cell survival and cooperates with c-myc to immortalize pre-B cells. Nature 1988; 335: 440-442.

12. McDonnell TJ, Deane N, Platt FM, Nuñez G, Jaeger U, McKearn JP et al. Bcl-2immunoglobulin transgenic mice demonstrate extended $B$ cell survival and follicular lymphoproliferation. Cell 1989; 57: 79-88.

13. Strasser A, Whittingham S, Vaux DL, Bath ML, Adams JM, Cory S et al. Enforced BCL2 expression in B-lymphoid cells prolongs antibody responses and elicits autoimmune disease. Proc Natl Acad Sci USA 1991; 88: 8661-8665.

14. Strasser A, Harris AW, Bath ML, Cory S. Novel primitive lymphoid tumours induced in transgenic mice by cooperation between myc and bcl-2. Nature 1990; 348: 331-333.

15. McDonnell TJ, Korsmeyer SJ. Progression from lymphoid hyperplasia to high-grade malignant lymphoma in mice transgenic for the $t(14 ; 18)$. Nature 1991; 349: 254-256.

16. Strasser A, Harris AW, Cory S. Em-bcl-2 transgene facilitates spontaneous transformation of early pre-B and immunoglobulin-secreting cells but not $T$ cells. Oncogene 1993; 8: 1-9.

17. Soucek L, Evan GI. The ups and downs of Myc biology. Curr Opin Genet Dev 2010; 20 91-95.

18. Pegoraro L, Palumbo A, Erikson J, Falda M, Giovanazzo B, Emanuel BS et al. A 14;18 and an $8 ; 14$ chromosome translocation in a cell line derived from an acute B-cell leukemia. Proc Natl Acad Sci USA 1984; 81: 7166-7170.

19. Boise LH, Gonzalez-Garcia M, Postema CE, Ding L, Lindsten T, Turka LA et al. Bcl-x, a $b c l-2$-related gene that functions as a dominant regulator of apoptotic cell death. Cell 1993; 74: 597-608

20. Oltvai ZN, Milliman CL, Korsmeyer SJ. Bcl-2 heterodimerizes in vivo with a conserved homolog, Bax, that accelerates programmed cell death. Cell 1993; 74: 609-619.

21. Oltvai ZN, Korsmeyer SJ. Checkpoints of dueling dimers foil death wishes. Cell 1994; 79 : 189-192.

22. Youle RJ, Strasser A. The BCL-2 protein family: opposing activities that mediate cell death. Nat Rev Mol Cell Biol 2008; 9: 47-59.

23. Veis DJ, Sorenson CM, Shutter JR, Korsmeyer SJ. Bcl-2-deficient mice demonstrate fulminant lymphoid apoptosis, polycystic kidneys, and hypopigmented hair. Cell 1993; 75 229-240.

24. Bouillet $P$, Cory S, Zhang LC, Strasser A, Adams JM. Degenerative disorders caused by Bcl-2 deficiency prevented by loss of its BH3-only antagonist Bim. Dev Cell 2001; 1 645-653.

25. Motoyama N, Wang FP, Roth KA, Sawa H, Nakayama K, Nakayama K et al. Massive cell death of immature hematopoietic cells and neurons in Bcl-x deficient mice. Science 1995; 267: $1506-1510$.

26. Print CG, Loveland KL, Gibson L, Meehan T, Stylianou A, Wreford N et al. Apoptosis regulator $\mathrm{Bcl}-\mathrm{W}$ is essential for spermatogenesis but appears otherwise redundant. Proc Natl Acad Sci USA 1998; 95: 12424-12431.

27. Rinkenberger JL, Horning S, Klocke B, Roth K, Korsmeyer SJ. Mcl-1 deficiency results in peri-implantation embryonic lethality. Genes Dev 2000; 14: 23-27.

28. Opferman JT, Letai A, Beard C, Sorcinelli MD, Ong CC, Korsmeyer SJ. Development and maintenance of B and T lymphocytes requires antiapoptotic MCL-1. Nature 2003; 426 671-676.

29. Vikstrom I, Carotta S, Luethje K, Peperzak V, Jost PJ, Glaser S et al. Mcl-1 is essential for germinal center formation and B cell memory. Science 2010; 330: 1095-1099. 
30. Xiang Z, Ahmed AA, Moller C, Nakayama K, Hatakeyama S, Nilsson G. Essential role of the prosurvival bcl-2 homologue $A 1$ in mast cell survival after allergic activation. $J$ Exp Med 2001; 194: 1561-1569.

31. Adams JM, Cory S. The Bcl-2 apoptotic switch in cancer development and therapy. Oncogene 2007; 26: 1324-1337.

32. Hanada M, Delia D, Aiello A, Stadmauer E, Reed JC. Bcl-2 gene hypomethylation and high-level expression in B-cell chronic lymphocytic leukemia. Blood 1993; 82: 1820-1828.

33. Kitada S, Andersen J, Akar S, Zapata JM, Takayama S, Krajewski S et al. Expression of apoptosis-regulating proteins in chronic lymphocytic leukemia: correlations with in vitro and in vivo chemoresponses. Blood 1998; 91: 3379-3389.

34. Robertson LE, Plunkett W, McConnell K, Keating MJ, McDonnell TJ. Bcl-2 expression in chronic lymphocytic leukemia and its correlation with the induction of apoptosis and clinical outcome. Leukemia 1996; 10: 456-459.

35. Ikegaki N, Katsumata M, Minna J, Tsujimoto Y. Expression of bcl-2 in small cell lung carcinoma cells. Cancer Res 1994; 54: 6-8.

36. Castle VP, Heidelberger KP, Bromberg J, Ou X, Dole M, Nuñez G. Expression of the apoptosis-suppressing protein $b c l-2$ in neuroblastoma is associated with unfavorable histology and N-myc amplification. Am J Pathol 1993; 143: 1543-1550.

37. Calin GA, Ferracin M, Cimmino A, Di Leva G, Shimizu M, Wojcik SE et al. A microRNA signature associated with prognosis and progression in chronic lymphocytic leukemia. N Engl J Med 2005; 353: 1793-1801.

38. Cimmino A, Calin GA, Fabbri M, Iorio MV, Ferracin M, Shimizu M et al. miR-15 and miR-16 induce apoptosis by targeting BCL2. Proc Natl Acad Sci USA 2005; 102 13944-13949.

39. Krajewski $S$, Krajewska $M$, Shabaik $A$, Wang $H G$, Irie $S$, Fong $L$ et al Immunohistochemical analysis of in vivo patterns of $\mathrm{Bcl}-\mathrm{X}$ expression. Cancer Res 1994; 54: 5501-5507.

40. Zhang B, Gojo I, Fenton RG. Myeloid cell factor-1 is a critical survival factor for multiple myeloma. Blood 2002; 99: 1885-1893.

41. Grillot DAM, Merino R, Pena JC, Fanslow WC, Finkelman FD, Thompson CB et al. Bcl-x exhibits regulated expression during $B$ cell development and activation and modulates lymphocyte survival in transgenic mice. J Exp Med 1996; 183: 381-391.

42. Cheung WC, Kim JS, Linden M, Peng L, Van Ness B, Polakiewicz RD et al. Novel targeted deregulation of $\mathrm{c}-\mathrm{Myc}$ cooperates with $\mathrm{Bcl}-\mathrm{X}(\mathrm{L})$ to cause plasma cell neoplasms in mice. J Clin Invest 2004; 113: 1763-1773.

43. Horita M, Andreu EJ, Benito A, Arbona C, Sanz C, Benet I et al. Blockade of the Bcr-Ab kinase activity induces apoptosis of chronic myelogenous leukemia cells by suppressing signal transducer and activator of transcription 5-dependent expression of $\mathrm{Bcl}-\mathrm{x}_{\llcorner}$. J Exp Med 2000; 191: 977-984

44. Beroukhim R, Mermel C, Porter D, Wei G, Raychaudhuri S, Donovan J et al. The landscape of somatic copy-number alteration across human cancers. Nature 2010; 463 899-905.

45. Kozopas KM, Yang T, Buchan HL, Zhou P, Craig RW. MCL1, a gene expressed in programmed myeloid cell differentiation, has sequence similarity to bcl-2. Proc Natl Acad Sci USA 1993; 90: 3516-3520.

46. Le Gouill S, Podar K, Amiot M, Hideshima T, Chauhan D, Ishitsuka K et al. VEGF induces Mcl-1 up-regulation and protects multiple myeloma cells against apoptosis. Blood 2004; 104: 2886-2892.

47. Kobayashi S, Werneburg NW, Bronk SF, Kaufmann SH, Gores GJ. Interleukin-6 contributes to $\mathrm{Mcl}-1$ up-regulation and TRAIL resistance via an Akt-signaling pathway in cholangiocarcinoma cells. Gastroenterology 2005; 128: 2054-2065.

48. Zhou P, Levy NB, Xie H, Qian L, Lee CY, Gascoyne RD et al. MCL1 transgenic mice exhibit a high incidence of B-cell lymphoma manifested as a spectrum of histologic subtypes. Blood 2001; 97: 3902-3909.

49. Campbell KJ, Bath ML, Turner ML, Vandenberg CJ, Bouillet $P$, Metcalf $D$ et al. Elevated Mcl-1 perturbs lymphopoiesis, promotes transformation of hematopoietic stem/progenito cells, and enhances drug resistance. Blood 2010; 116: 3197-3207.

50. Brunelle JK, Ryan J, Yecies D, Opferman JT, Letai A. MCL-1-dependent leukemia cells are more sensitive to chemotherapy than BCL-2-dependent counterparts. J Cell Biol 2009; 187: 429-442.

51. Cho-Vega JH, Rassidakis GZ, Admirand JH, Oyarzo M, Ramalingam P, Paraguya A et al MCL-1 expression in B-cell non-Hodgkin's lymphomas. Hum Pathol 2004; 35: 1095-1100.

52. Oltersdorf T, Elmore SW, Shoemaker AR, Armstrong RC, Augeri DJ, Belli BA et al. An inhibitor of Bcl-2 family proteins induces regression of solid tumours. Nature 2005; 435 $677-681$

53. Konopleva M, Contractor R, Tsao T, Samudio I, Ruvolo PP, Kitada S et al. Mechanisms of apoptosis sensitivity and resistance to the $\mathrm{BH} 3$ mimetic $\mathrm{ABT}-737$ in acute myeloid leukemia. Cancer Cell 2006; 10: 375-388.

54. van Delft MF, Wei AH, Mason KD, Vandenberg CJ, Chen L, Czabotar PE et al. The BH3 mimetic ABT-737 targets selective Bcl-2 proteins and efficiently induces apoptosis via $\mathrm{Bak} / \mathrm{Bax}$ if Mcl-1 is neutralized. Cancer Cell 2006; 10: 389-399.

55. Lin EY, Orlofsky A, Berger MS, Prystowsky MB. Characterization of A1, a novel hemopoietic-specific early-response gene with sequence similarity to bcl-2. J Immunol 1993; 151: 1979-1988.

56. Feuerhake F, Kutok JL, Monti S, Chen W, LaCasce AS, Cattoretti G et al. NFkappaB activity, function, and target-gene signatures in primary mediastinal large B-cel lymphoma and diffuse large B-cell lymphoma subtypes. Blood 2005; 106: 1392-1399.
57. Brien G, Trescol-Biemont MC, Bonnefoy-Berard N. Downregulation of Bfl-1 protein expression sensitizes malignant B cells to apoptosis. Oncogene 2007; 26: 5828-5832.

58. Nieborowska-Skorska M, Hoser G, Kossev P, Wasik MA, Skorski T. Complementary functions of the antiapoptotic protein $\mathrm{A} 1$ and serine/threonine kinase pim-1 in the BCR/ ABL-mediated leukemogenesis. Blood 2002; 99: 4531-4539.

59. Bae IH, Park MJ, Yoon SH, Kang SW, Lee SS, Choi KM et al. Bcl-w promotes gastric cancer cell invasion by inducing matrix metalloproteinase-2 expression via phosphoinositide 3-kinase, Akt, and Sp1. Cancer Res 2006; 66: 4991-4995.

60. Wilson JW, Nostro MC, Balzi M, Faraoni P, Cianchi F, Becciolini A et al. Bcl-w expression in colorectal adenocarcinoma. Br J Cancer 2000; 82: 178-185.

61. Letai A, Sorcinelli MD, Beard C, Korsmeyer SJ. Antiapoptotic BCL-2 is required for maintenance of a model leukemia. Cancer Cell 2004; 6: 241-249.

62. Merino R, Ding L, Veis DJ, Korsmeyer SJ, Nuñez G. Developmental regulation of the Bcl2 protein and susceptibility to cell death in B lymphocytes. EMBO J 1994; 13: 683-691.

63. Kelly PN, Puthalakath $\mathrm{H}$, Adams JM, Strasser A. Endogenous bcl-2 is not required for the development of $\mathrm{E} \mu$-myc-induced B-cell lymphoma. Blood 2007; 109: 4907-4913.

64. Linden M, Kirchhof N, Carlson C, Van Ness B. Targeted overexpression of Bcl-XL in B-lymphoid cells results in lymphoproliferative disease and plasma cell malignancies. Blood 2004; 103: 2779-2786.

65. Chipuk JE, Green DR. How do BCL-2 proteins induce mitochondrial outer membrane permeabilization? Trends Cell Biol 2008; 18: 157-164.

66. Lindsten T, Ross AJ, King A, Zong W, Rathmell JC, Shiels HA et al. The combined functions of proapoptotic Bcl-2 family members Bak and Bax are essential for normal development of multiple tissues. Mol Cell 2000; 6: 1389-1399.

67. Knudson CM, Tung KSK, Tourtellotte WG, Brown GAJ, Korsmeyer SJ. Bax-deficient mice with lymphoid hyperplasia and male germ cell death. Science 1995; 270: 96-99.

68. Wei MC, Zong WX, Cheng EH, Lindsten T, Panoutsakopoulou V, Ross AJ et al. Proapoptotic BAX and BAK: a requisite gateway to mitochondrial dysfunction and death. Science 2001; 292: 727-730.

69. Zong WX, Lindsten T, Ross AJ, MacGregor GR, Thompson CB. BH3-only proteins that bind pro-survival $\mathrm{Bcl}-2$ family members fail to induce apoptosis in the absence of $\mathrm{Bax}$ and Bak. Genes Dev 2001; 15: 1481-1486.

70. Eischen CM, Roussel MF, Korsmeyer SJ, Cleveland JL. Bax loss impairs Myc-induced apoptosis and circumvents the selection of p53 mutations during Myc-mediated lymphomagenesis. Mol Cell Biol 2001; 21: 7653-7662.

71. Rathmell JC, Lindsten T, Zong W-X, Cinalli RM, Thompson CB. Deficiency in Bak and Bax perturbs thymic selection and lymphoid homeostasis. Nat Immunol 2002; 3: 932-939.

72. Huang DCS, Strasser A. BH3-only proteins - essential initiators of apoptotic cell death. Cell 2000; 103: 839-842.

73. Villunger A, Michalak EM, Coultas L, Müllauer F, Böck G, Ausserlechner MJ et al. p53and drug-induced apoptotic responses mediated by $\mathrm{BH} 3$-only proteins Puma and Noxa. Science 2003; 302: 1036-1038.

74. Jeffers JR, Parganas E, Lee Y, Yang C, Wang J, Brennan J et al. Puma is an essential mediator of p53-dependent and -independent apoptotic pathways. Cancer Cell 2003; 4: 321-328.

75. Bouillet $P$, Metcalf D, Huang DCS, Tarlinton DM, Kay TWH, Köntgen F et al. Proapoptotic $\mathrm{Bcl}-2$ relative Bim required for certain apoptotic responses, leukocyte homeostasis, and to preclude autoimmunity. Science 1999; 286: 1735-1738.

76. Puthalakath H, O'Reilly LA, Gunn P, Lee L, Kelly PN, Huntington ND et al. ER stress triggers apoptosis by activating BH3-only protein Bim. Cell 2007; 129: 1337-1349.

77. Michalak EM, Villunger A, Adams JM, Strasser A. In several cell types the tumour suppressor p53 induces apoptosis largely via Puma but Noxa can contribute. Cell Death Differ 2008; 15: 1019-1029.

78. Erlacher M, Laabi V, Manzl C, Bock G, Tzankov A, Haecker G et al. Puma cooperates with $\mathrm{Bim}$, the rate-limiting $\mathrm{BH} 3$-only protein in cell death during lymphocyte development, in apoptosis induction. J Exp Med 2006; 203: 2939-2951.

79. Erlacher M, Michalak EM, Kelly PN, Labi V, Niederegger $\mathrm{H}$, Coultas L et al. BH3-only proteins Puma and Bim are rate-limiting for \{gamma\} -radiation and glucocorticoidinduced apoptosis of lymphoid cells in vivo. Blood 2005; 106: 4131-4138.

80. Egle A, Harris AW, Bouillet $P$, Cory S. Bim is a suppressor of Myc-induced mouse $B$ cell leukemia. Proc Natl Acad Sci USA 2004; 101: 6164-6169.

81. Garrison SP, Jeffers JR, Yang C, Nilsson JA, Hall MA, Rehg JE et al. Selection against PUMA gene expression in Myc-driven B-cell lymphomagenesis. Mol Cell Biol 2008; 28: 5391-5402.

82. Michalak EM, Jansen ES, Happo L, Cragg MS, Tai L, Smyth GK et al. Puma and to a lesser extent Noxa are suppressors of Myc-induced lymphomagenesis. Cell Death Differ 2009; 16: 684-696.

83. Tagawa H, Karnan S, Suzuki R, Matsuo K, Zhang X, Ota A et al. Genome-wide arraybased CGH for mantle cell lymphoma: identification of homozygous deletions of the proapoptotic gene BIM. Oncogene 2005; 24: 1348-1358.

84. Sattler M, Liang H, Nettesheim D, Meadows RP, Harlan JE, Eberstadt M et al. Structure of Bcl- $x_{L}$-Bak peptide complex: recognition between regulators of apoptosis. Science 1997; 275: $983-986$

85. Liu X, Dai S, Zhu Y, Marrack $P$, Kappler JW. The structure of a Bcl-x//Bim fragment complex: implications for Bim function. Immunity 2003; 19: 341-352.

86. Chen L, Willis SN, Wei A, Smith BJ, Fletcher Jl, Hinds MG et al. Differential targeting of pro-survival Bcl-2 proteins by their BH3-only ligands allows complementary apoptotic function. Mol Cell 2005; 17: 393-403. 
87. Kuwana T, Bouchier-Hayes L, Chipuk JE, Bonzon C, Sullivan BA, Green DR et al. BH3 domains of BH3-only proteins differentially regulate Bax-mediated mitochondrial membrane permeabilization both directly and indirectly. Mol Cell 2005; 17: 525-535.

88. Cheng EH, Wei MC, Weiler S, Flavell RA, Mak TW, Lindsten T et al. BCL-2, BCL-X sequester $\mathrm{BH} 3$ domain-only molecules preventing $\mathrm{BAX}$ - and BAK-mediated mitochondrial apoptosis. Mol Cell 2001; 8: 705-711.

89. Letai A, Bassik M, Walensky L, Sorcinelli M, Weiler S, Korsmeyer S. Distinct BH3 domains either sensitize or activate mitochondrial apoptosis, serving as prototype cancer therapeutics. Cancer Cell 2002; 2: 183-192.

90. Chipuk JE, Fisher JC, Dillon CP, Kriwacki RW, Kuwana T, Green DR. Mechanism of apoptosis induction by inhibition of the anti-apoptotic BCL-2 proteins. Proc Natl Acad Sci USA 2008; 105: 20327-20332.

91. Billen LP, Kokoski CL, Lovell JF, Leber B, Andrews DW. Bcl-XL inhibits membrane permeabilization by competing with Bax. PLOS Biol 2008; 6: e147.

92. Willis SN, Fletcher Jl, Kaufmann T, van Delft MF, Chen L, Czabotar PE et al. Apoptosis initiated when $\mathrm{BH} 3$ ligands engage multiple Bcl-2 homologs, not Bax or Bak. Science 2007; 315: 856-859.

93. Ren D, Tu HC, Kim H, Wang GX, Bean GR, Takeuchi O et al. BID, BIM, and PUMA are essential for activation of the BAX- and BAK-dependent cell death program. Science 2010; 330: 1390-1393.

94. Merino D, Giam M, Hughes PD, Siggs OM, Heger K, O'Reilly LA et al. The role of BH3only protein Bim extends beyond inhibiting Bcl-2-like prosurvival proteins. J Cell Biol 2009; 186: $355-362$.
95. Happo L, Cragg MS, Phipson B, Haga JM, Jansen ES, Herold MJ et al. Maximal killing of lymphoma cells by DNA-damage inducing therapy requires not only the p53 targets Puma and Noxa but also Bim. Blood 2010; 116: 5256-5267.

96. Kuroda J, Puthalakath $\mathrm{H}$, Cragg MS, Kelly PN, Bouillet P, Huang DC et al. Bim and Bad mediate imatinib-induced killing of $\mathrm{Bcr} / \mathrm{Abl}+$ leukemic cells, and resistance due to their loss is overcome by a BH3 mimetic. Proc Natl Acad Sci USA 2006; 103: 14907-14912.

97. Cragg MS, Kuroda J, Puthalakath H, Huang DCS, Strasser A. Gefitinib-induced killing of NSCLC cell lines expressing mutant EGFR requires Bim and can be enhanced by $\mathrm{BH} 3$ mimetics. PLoS Med 2007; 4: 1681-1689.

98. Costa DB, Halmos B, Kumar A, Schumer ST, Huberman MS, Boggon TJ et al. BIM mediates EGFR tyrosine kinase inhibitor-induced apoptosis in lung cancers with oncogenic EGFR mutations. PLoS Med 2007; 4: e315.

99. Gong Y, Somwar R, Politi K, Balak M, Chmielecki J, Jiang X et al. Induction of BIM is essential for apoptosis triggered by EGFR kinase inhibitors in mutant EGFR-dependent lung adenocarcinomas. PLOS Med 2007; 4: e294.

100. Cragg MS, Jansen ES, Cook M, Harris C, Strasser A, Scott CL. Treatment of B-RAF mutant human tumor cells with a MEK inhibitor requires Bim and is enhanced by a $\mathrm{BH} 3$ mimetic. J Clin Invest 2008; 118: 3651-3659.

101. Deng J, Carlson N, Takeyama K, Dal Cin P, Shipp M, Letai A. BH3 profiling identifies three distinct classes of apoptotic blocks to predict response to ABT-737 and conventional chemotherapeutic agents. Cancer Cell 2007; 12: 171-185.

102. Letai AG. Diagnosing and exploiting cancer's addiction to blocks in apoptosis. Nat Rev Cancer 2008; 8: 121-132. 